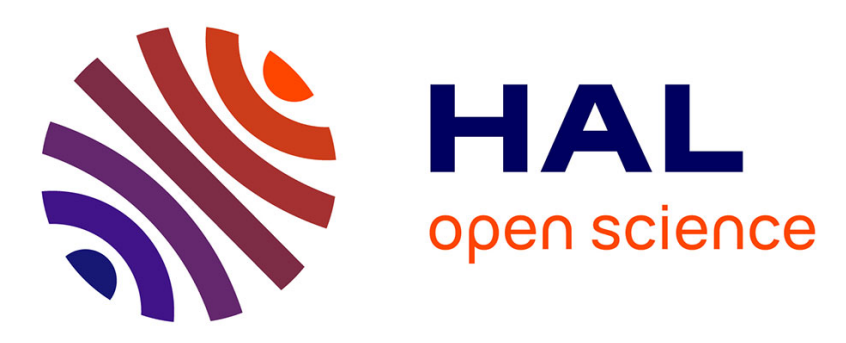

\title{
Ecological characterization of intertidal rockpools: Seasonal and diurnal monitoring of physico-chemical parameters
}

\author{
Erwann Legrand, Pascal Riera, Loïc Pouliquen, Olivier Bohner, Thierry \\ Cariou, Sophie Martin
}

\section{To cite this version:}

Erwann Legrand, Pascal Riera, Loïc Pouliquen, Olivier Bohner, Thierry Cariou, et al.. Ecological characterization of intertidal rockpools: Seasonal and diurnal monitoring of physico-chemical parameters. Regional Studies in Marine Science, 2018, 17, pp.1 - 10. 10.1016/j.rsma.2017.11.003 . hal-01829996

\section{HAL Id: hal-01829996 https://hal.sorbonne-universite.fr/hal-01829996}

Submitted on 4 Jul 2018

HAL is a multi-disciplinary open access archive for the deposit and dissemination of scientific research documents, whether they are published or not. The documents may come from teaching and research institutions in France or abroad, or from public or private research centers.
L'archive ouverte pluridisciplinaire HAL, est destinée au dépôt et à la diffusion de documents scientifiques de niveau recherche, publiés ou non, émanant des établissements d'enseignement et de recherche français ou étrangers, des laboratoires publics ou privés. 


\title{
Ecological characterization of intertidal rockpools: Seasonal and diurnal monitoring of physico-chemical parameters
}

\author{
Erwann Legrand ${ }^{\mathrm{a}, \mathrm{b}, *}$, Pascal Riera ${ }^{\mathrm{a}, \mathrm{b}}$, Loïc Pouliquen ${ }^{\mathrm{a}, \mathrm{b}}$, Olivier Bohner ${ }^{\mathrm{a}, \mathrm{b}}$, \\ Thierry Cariou ${ }^{\mathrm{a}, \mathrm{c}}$, Sophie Martin ${ }^{\mathrm{a}, \mathrm{b}}$ \\ a Sorbonne Universités, UPMC Univ Paris 06, Station Biologique, Place Georges Teissier, 29688 Roscoff Cedex, France \\ b CNRS, UMR7144, Station Biologique, Place Georges Teissier, 29688 Roscoff Cedex, France \\ c CNRS, FR2424, Station Biologique, Place Georges Teissier, 29688 Roscoff Cedex, France
}

\section{GRAPHICAL ABSTRACT}

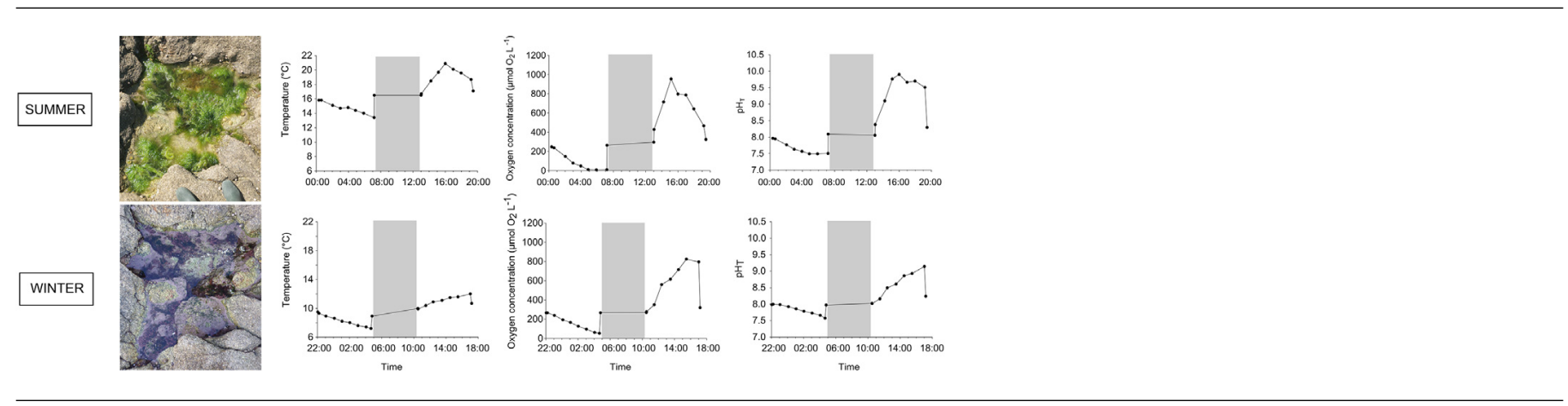

\section{A B S T R A C T}

Keywords:

Rockpool

Seasonal variation

Diurnal variability

Coralline algae

Fleshy algae
Diurnal and seasonal variations in temperature, salinity, oxygen concentration, carbonate chemistry parameters and nutrient concentration were monitored within mid-tidal rockpools on the north-western coast of Brittany, France. We also examined the importance of rockpool physical characteristics (e.g. shore height, surface, volume and depth) on the physico-chemical variability. Rockpool shore height and depth appeared as the main physical factors driving physico-chemical variations. Shallow upper shore rockpools exhibited the largest diurnal and seasonal fluctuations of temperature, oxygen concentration and $\mathrm{pH}_{\mathrm{T}}$. Conversely, deeper and lower shore rockpools experienced weaker variations, excepted for salinity and nutrient concentrations. The physico-chemical environment was likely to be strongly influenced by rockpool community composition, especially in summer when rockpools were colonized by dense canopy-forming algae. During the day-time emersion, photosynthesis increased oxygen concentration and $\mathrm{pH}_{\mathrm{T}}$ but decreased nutrient concentrations in upper shore rockpools. The increase in rockpool $\mathrm{pH}_{\mathrm{T}}$ provided an alkaline environment conducive to coralline algal calcification. Conversely, at night, upper shore rockpools presented a strong decrease in oxygen concentration and $\mathrm{pH}_{\mathrm{T}}$ due to the high community respiration, increasing the dissolution in coralline algae. Therefore, rockpools are characterized by complex interactions between physical and chemical parameters and biological processes. Rockpools appear as suitable environments to examine the physiological processes set up by species to face natural variability, especially in a context of climate change.

\footnotetext{
* Corresponding author.

E-mail address: erwann.legrand@sb-roscoff.fr (E. Legrand).
}

\section{Introduction}

Intertidal communities are exposed to a dynamic environment influenced by tidal flooding (Widdows and Brinsley, 2002). Organisms living at the interface between land and sea are exposed 
to consecutive periods of emersion and immersion. During low tides, organisms undergo harsh environmental conditions characterized by high temperature variations and solar radiation, low humidity and windy conditions (Martínez et al., 2012; Tomanek and Helmuth, 2002). These physical conditions take species close to their physiological thresholds (Fernández et al., 2015), through a rapid desiccation and damages to photosynthetic and cellular components (Collén and Davison, 1999; Hoffman et al., 2003).

On the sea shore, rockpools are patchy depressions which retain seawater during low tide. This intertidal marine environment acts as refuge for many intertidal species (Underwood and Jernakoff, 1984; Zander et al., 1999), due to the lower amplitude of physico-chemical fluctuations compared with emerging substrate (Metaxas and Scheibling, 1993). However, physico-chemical variations within rockpools remain much greater than those of nearshore seawater (Morris and Taylor, 1983). Strong diurnal and seasonal variations in rockpools have been recorded for temperature, oxygen concentration, pH and salinity (Daniel and Boyden, 1975; Morris and Taylor, 1983), but never in terms of whole carbonate chemistry and nutrients. In addition to temporal variations, rockpool physico-chemical parameters are highly variable in space, depending mainly on the wave exposure and the shore height (Firth et al., 2013; Martins et al., 2007).

Rockpools are also characterized by strong interactions between physico-chemical parameters and biological processes (Benedetti-Cecchi et al., 2000; Underwood and Jernakoff, 1984). In particular, species distribution and abundance are controlled by both abiotic factors (Huggett and Griffiths, 1986; Metaxas and Scheibling, 1993; Truchot and Duhamel-Jouve, 1980) and species interactions, such as herbivory, predation and competition (Metaxas and Scheibling, 1993). The high productivity observed in these habitats is mostly explained by the diversity of seaweeds (Araujo et al., 2006) and invertebrates (Ganning, 1971) which develop in rockpools (Firth et al., 2014).

In this context, the present study aims to (1) quantify diurnal and seasonal variations in multiple physico-chemical parameters (e.g. temperature, salinity, oxygen concentration, carbonate chemistry and nutrient concentration), which naturally occur within intertidal rockpools and (2) assess the importance of rockpool physical characteristics (e.g. shore height, surface, volume and depth) on the physico-chemical variability. Seasonal variations within rockpools were examined over a period of 14 months, during which two diurnal monitoring of physicochemical parameters were carried out, one in the winter and one in the summer. Finally, the composition of the community present in each rockpool was examined in the winter and the summer to better understand the influence exerted by biotic factors on the physico-chemical variability.

\section{Materials and methods}

\subsection{Seasonal monitoring}

From January 2015 to March 2016, 5 rockpools were monitored every 2 weeks during spring tides under fair weather conditions. Rockpools were situated in a rocky shore at the Bloscon site in Roscoff, Brittany, France ( $\left.48^{\circ} 43^{\prime} 28 N^{\circ} 03^{\circ} 58^{\prime} 08 \mathrm{~W}\right)$. Rockpools monitored were distributed at different heights above chart datum (C.D., Table 1 ) in the mid-tidal zone and were colonized by coralline algae, non-calcareous algae and associated fauna (Fig. 1). All selected rockpools were filled with seawater at each high tide and were isolated from the sea at each low tide. Selected rockpools presented different volumes and depth to assess relationships between physical structure, physico-chemical variability and assemblage composition.

Measurements of temperature, dissolved oxygen concentration, $\mathrm{pH}_{\mathrm{T}}$ ( $\mathrm{pH}$ expressed on the total hydrogen ion concentration scale) and salinity were performed at different locations across of each rockpool, using a multimeter (HQ40D, Hach Lange, Ltd portable LDO). All measurements and samples were made at the end of the emersion of rockpools, just before they were covered by the tide. Throughout the year, measurements were made at the same positions and depth in each rockpool and seawater was homogenized before each measurement. Seawater $\mathrm{pH}$ and temperature measurements were realized using a probe associated with a temperature sensor with an accuracy of $0.3^{\circ} \mathrm{C}$ and $0.02 \mathrm{pH}$ units, respectively (PHC101, Hach Lange, IntelliCAL). The $\mathrm{pH}$ probe was calibrated using Tris/HCl and 2-aminopyridine/HCl buffers (Dickson et al., 2007). Dissolved oxygen concentrations ( $\mathrm{mg} \mathrm{L}^{-1}$ ) were measured with a luminescent dissolved oxygen probe (LD0101, Hach Lange, IntelliCAL) with an accuracy of $0.02 \mathrm{mg} \mathrm{L}^{-1}$ and converted to oxygen concentrations in $\mu \mathrm{mol} \mathrm{L}^{-1}$. Salinity was determined using a conductivity probe (CDC401, Hach Lange, IntelliCAL, accuracy of 0.1 ). Seawater samples were also taken in the rockpools for total alkalinity $\left(A_{\mathrm{T}}\right)$ measurements. $60 \mathrm{~mL}$ seawater samples for $A_{\mathrm{T}}$ analyses were filtered through $0.7 \mu \mathrm{m}$ Whatman $\mathrm{GF} / \mathrm{F}$ filters and poisoned with a mercuric chloride solution to prevent biological activity (Dickson et al., 2007). $A_{\mathrm{T}}$ was determined by an opencell titration on an automatic titrator (Titroline alpha, Schott SI Analytics, Mainz, Germany) according to the method developed by Dickson et al. (2007). $A_{\mathrm{T}}$ was calculated using a Gran function applied to pH values ranging from 3.5 to 3.0 (Dickson et al., 2007) and corrected using standard reference material provided by Andrew G. Dickson (CRM Batch 111). Saturation state of seawater with respect to aragonite $\left(\Omega_{\mathrm{Ar}}\right)$ and saturation state of seawater with respect to calcite $\left(\Omega_{\mathrm{Ca}}\right)$ were calculated from $\mathrm{pH}_{\mathrm{T}}, A_{\mathrm{T}}$, temperature and salinity using the CO2SYS software (Lewis and Wallace, 1998), using constants from Mehrbach et al. (1973) refitted by Dickson and Millero (1987). Nitrite $\left(\mathrm{NO}_{2}^{-}, \mu \mathrm{mol} \mathrm{L}{ }^{-1}\right)$, nitrate $\left(\mathrm{NO}_{3}^{-}, \mu \mathrm{mol}\right.$ $\left.\mathrm{L}^{-1}\right)$, phosphate $\left(\mathrm{PO}_{4}^{3-}, \mu \mathrm{mol} \mathrm{L}{ }^{-1}\right)$ and silicate $\left(\mathrm{Si}(\mathrm{OH})_{4}, \mu \mathrm{mol} \mathrm{L}{ }^{-1}\right)$ concentrations were monitored once a month. For $\mathrm{NO}_{2}^{-}, \mathrm{NO}_{3}^{-}$and $\mathrm{PO}_{4}^{3-}$ measurements, $60 \mathrm{~mL}$ of seawater was sampled and filtered through $0.7 \mu \mathrm{m}$ Whatman $\mathrm{GF} / \mathrm{F}$ filters in $100 \mathrm{~mL}$ plastic containers. Then, samples were frozen $\left(-20{ }^{\circ} \mathrm{C}\right)$ pending analyses. For $\mathrm{Si}(\mathrm{OH})_{4}, 60 \mathrm{~mL}$ seawater samples were filtered through $0.8 \mu \mathrm{m}$ Millex cellulose ester filters in $100 \mathrm{~mL}$ plastic containers and were kept refrigerated pending analyses. Nutrient samples were measured using a AA3 auto-analyzer (Seal Analytical) according to the method of Aminot and Kérouel (2007), with an accuracy of $1 \mathrm{nmol}$ $\mathrm{L}^{-1}$ for $\mathrm{NO}_{2}^{-}, 0.02 \mu \mathrm{mol} \mathrm{L}^{-1}$ for $\mathrm{NO}_{3}^{-}, 1 \mathrm{nmol} \mathrm{L}^{-1}$ for $\mathrm{PO}_{4}^{3-}$, and 0.01 $\mu \mathrm{mol} \mathrm{L}^{-1}$ for $\mathrm{Si}(\mathrm{OH})_{4}$. Seasonal physico-chemical parameters were compared with those of near shore seawater (when available), obtained from SOMLIT (Service d'Observation en Milieu LITtoral, INSU-CNRS) station, located in the Estacade site in Roscoff.

\subsection{Diurnal monitoring}

Among the five rockpools chosen for the seasonal monitoring, three of them were selected for diurnal measurements (rockpools 2, 4 and 5, Table 1). Two 24-h monitoring were realized during spring tides, in summer (September 3rd, 2015) and in winter (March 10th, 2016). Measurements of temperature, $\mathrm{pH}_{\mathrm{T}}$, oxygen concentration, salinity and $A_{\mathrm{T}}$ were realized every hour during the emersion period, and $\Omega_{\mathrm{Ar}}$ and $\Omega_{\mathrm{Ca}}$ were calculated as described above. Near shore seawater was also monitored and sampled just before and after the emersion period. All samples were analyzed as described above.

\subsection{Community composition}

After the one-year monitoring, biomass sampling was realized in the 5 rockpools in summer and in winter. $10 \times 10 \mathrm{~cm}$ quadrats were randomly placed in rockpools and all the seaweeds and 
Table 1

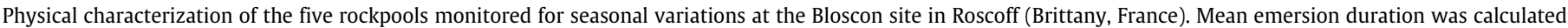

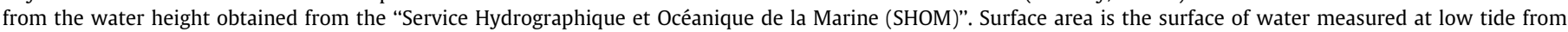
pictures. Min and max emersion duration were determined over January 2015 to March 2016.

\begin{tabular}{|c|c|c|c|c|c|c|c|c|}
\hline Rockpool & $\begin{array}{l}\text { Shore } \\
\text { height }(\mathrm{m})\end{array}$ & $\begin{array}{l}\text { Mean emersion } \\
\text { duration }(\mathrm{h})\end{array}$ & $\begin{array}{l}\text { Min emersion } \\
\text { duration }(\mathrm{h})\end{array}$ & $\begin{array}{l}\text { Max emersion } \\
\text { duration }(\mathrm{h})\end{array}$ & Surface area $\left(\mathrm{m}^{2}\right)$ & Volume $\left(\mathrm{m}^{3}\right)$ & $\begin{array}{l}\text { Maximum } \\
\text { depth }(\mathrm{cm})\end{array}$ & Surface/volume ratio \\
\hline 1 & 6.4 & $7 \mathrm{~h} 40$ & 7 h 01 & 10 h 13 & 2.58 & 0.294 & 23 & 8.77 \\
\hline 2 & 6.2 & $7 \mathrm{~h} 20$ & 6 h 51 & 9 h 22 & 0.54 & 0.063 & 25 & 8.56 \\
\hline 3 & 5.8 & $6 \mathrm{~h} 40$ & $6 \mathrm{~h} 33$ & 8 h 02 & 0.79 & 0.175 & 31 & 4.50 \\
\hline 4 & 4.9 & $5 \mathrm{~h} 30$ & 5 h 25 & 5 h 47 & 0.57 & 0.087 & 32 & 6.51 \\
\hline 5 & 4.4 & $4 \mathrm{~h} 40$ & 3 h 55 & 5 h 23 & 1.16 & 0.234 & 46 & 4.95 \\
\hline
\end{tabular}

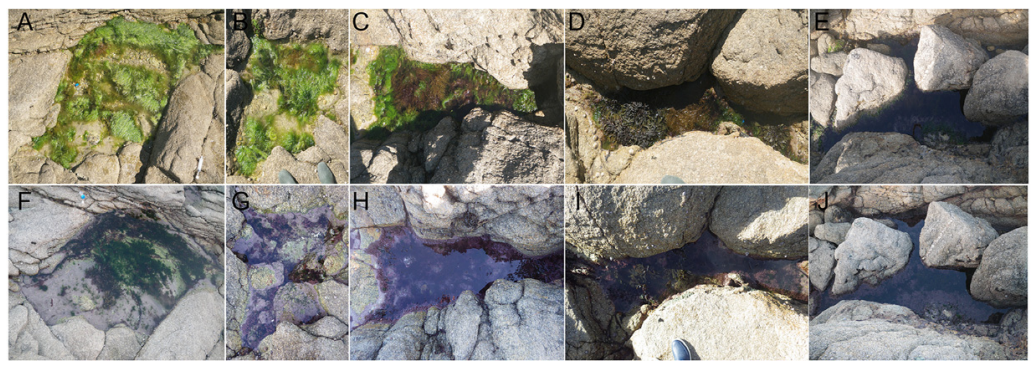

Fig. 1. Pictures of rockpools 1 to 5 in summer (A to E) and winter (F to J). All rockpools were located in the Estacade site in Roscoff (Brittany, France).

animals in the quadrats were sampled. The number of quadrats per rockpool depended on the size of the rockpools ( 4 quadrats for rockpools 2 and 4, 5 quadrats for rockpool 3 and 8 quadrats for rockpools 1 and 5). In the laboratory, macrofauna and seaweed species were sorted and the main species were identified. Species dry weight (DW) was determined after drying fresh samples at $60{ }^{\circ} \mathrm{C}$ for $48 \mathrm{~h}$. Species were then burned for $6 \mathrm{~h}$ at $500{ }^{\circ} \mathrm{C}$ in a furnace to obtain ash-free dry weight (AFDW; Crisp, 1984). For the CCA $L$. incrustans, the biomass could not be determined precisely without deteriorating rockpools. Therefore, the cover percent was estimated for each quadrat and AFDW was obtained from previously established relationships between the surface covered by the alga and the AFDW.

\subsection{Data analysis}

Differences in physico-chemical parameters among rockpools were examined from seasonal data using a three-way permutational multivariate analysis of variance (PERMANOVA), based on Euclidian distance (Anderson, 2001). PERMANOVAs were run with 4999 permutations (Anderson, 2001). These statistical analyses were performed with the PRIMER 7 \& PERMANOVA+ software package. The Principal component analysis (PCA) was completed using R 3.2.2 version from seasonal data. The PCA was performed using the "factoextra" package to test the correlation between environmental and physical variables and determine which variables explain most of the space-time variability observed between rockpools.

\section{Results}

\subsection{Seasonal variations}

The physico-chemical parameters exhibited significant differences between rockpools (PERMANOVA, $F=44.9, \mathrm{p}<0.001$, $n=29$ ) except between rockpools 3 and 4 (Table 2, Figs. 2 and 3 ). The rockpools 1 and 2 showed the largest amplitude for all physico-chemical parameters, except for salinity and nutrient concentrations. Conversely, the rockpool 5 presented weak seasonal variations for all parameters except for salinity and nutrient concentrations, which exhibited the largest variations. Physicochemical parameters showed strong differences according to seasons. At the end of the emersion period, the seawater temperature within rockpools varied from $7.9^{\circ} \mathrm{C}$ in February 2015 in rockpool 3 to $26.9^{\circ} \mathrm{C}$ in July in rockpool 1 . Minimum oxygen concentrations were recorded in the rockpool 5 in January $2016\left(242 \mu \mathrm{mol} \mathrm{O}_{2} \mathrm{~L}^{-1}\right)$, while maximum concentrations were obtained in the rockpool 1 in November, reaching $1040 \mu \mathrm{mol} \mathrm{O}_{2} \mathrm{~L}^{-1}$. The rockpool 5 showed the lowest salinity in January (33.4), while the highest values were recorded in rockpool 2 in May and August (36.6). The minimum $\mathrm{pH}_{\mathrm{T}}$ was 7.79 and was measured in rockpool 5 in January 2016. The maximum $\mathrm{pH}_{\mathrm{T}}$ value was 10.01, recorded in rockpool 1 in April. $A_{\mathrm{T}}$ varied from $1553 \mu \mathrm{mol} \mathrm{L}^{-1}$ in early September to $2588 \mu \mathrm{mol} \mathrm{L}-1$ in late January 2016 in rockpools 2 and 5, respectively. Carbonate saturation states of seawater with respect to aragonite $\left(\Omega_{\mathrm{Ar}}\right)$ and calcite $\left(\Omega_{\mathrm{Ca}}\right)$ are the lowest in rockpool 5 in January 2016 (1.3 and 2.1 , respectively) and the highest in rockpool 1 in May (11.5 and 17.9 , respectively).

$\mathrm{NO}_{2}^{-}$concentrations varied from $0.00 \mu \mathrm{mol} \mathrm{L}^{-1}$ in August in rockpool 1 to $0.65 \mu \mathrm{mol} \mathrm{L}^{-1}$ in early September in rockpool 5 (Fig. 3). The rockpool 1 also presented the lowest $\mathrm{NO}_{3}^{-}(0.06 \mu \mathrm{mol}$ $\left.\mathrm{L}^{-1}\right)$ and $\mathrm{PO}_{4}^{3-}\left(0.04 \mu \mathrm{mol} \mathrm{L}^{-1}\right)$ concentrations in May and June, respectively. The highest $\mathrm{NO}_{3}^{-}$and $\mathrm{PO}_{4}^{3-}$ concentrations were measured in rockpool 5 in late January $2016\left(19.65 \mu \mathrm{mol} \mathrm{NO}_{3}^{-} \mathrm{L}^{-1}\right)$ and early March $2015\left(1.07 \mu \mathrm{mol} \mathrm{PO}_{4}^{3-} \mathrm{L}^{-1}\right)$, respectively. Si $(\mathrm{OH})_{4}$ concentrations reached minimum concentrations of $0.51 \mu \mathrm{mol} \mathrm{L}^{-1}$ in rockpool 3 in April and maximum concentrations of $7.41 \mu \mathrm{mol}$ $\mathrm{L}^{-1}$ in rockpool 5 in September.

The first principal component (PC1) of the PCA was strongly positively correlated with depth, nutrients and $A_{\mathrm{T}}$ and negatively correlated with increasing shore height, $\mathrm{pH}_{\mathrm{T}}$, oxygen concentration and salinity (Fig. 4a). The second principal component (PC2) indicated an opposition between temperature and oxygen concentration. The different nutrients were clearly positively correlated between them and $A_{\mathrm{T}}$, but negatively correlated with oxygen concentration, $\mathrm{pH}_{\mathrm{T}}$, temperature and salinity.

From the PCA, the within-rockpool seasonal variability appeared mainly driven by temperature (Fig. 4b). The rockpool 5 differed from the others through much higher nutrient concentrations and $A_{\mathrm{T}}$, and lower $\mathrm{pH}_{\mathrm{T}}$, salinity and oxygen concentrations. Conversely, the rockpools 1 and 2 were characterized by high $\mathrm{pH}_{\mathrm{T}}$, salinity and oxygen concentrations, but low nutrient concentration and $A_{\mathrm{T}}$. 
Table 2

Results of PERMANOVA's post-hoc pairwise tests performed on the physico-chemical parameters obtained from the seasonal monitoring of the five rockpools $(n=29)$. Significant results are in bold $(\mathrm{p}<0.05)$.

\begin{tabular}{|c|c|c|c|c|c|c|c|c|}
\hline & \multicolumn{2}{|c|}{ Rockpool 1} & \multicolumn{2}{|c|}{ Rockpool 2} & \multicolumn{2}{|c|}{ Rockpool 3} & \multicolumn{2}{|c|}{ Rockpool 4} \\
\hline & $\mathrm{t}$ & $\mathrm{p}$ & $\mathrm{t}$ & $\mathrm{p}$ & $\mathrm{t}$ & $\mathrm{p}$ & $\mathrm{t}$ & $\mathrm{p}$ \\
\hline Rockpool 2 & 2.5 & 0.004 & - & - & - & - & - & - \\
\hline Rockpool 3 & 3.0 & $<0.001$ & 3.7 & $<0.001$ & - & - & - & - \\
\hline Rockpool 4 & 3.3 & $<0.001$ & 2.9 & $<0.001$ & 1.5 & 0.14 & - & - \\
\hline Rockpool 5 & 11.1 & $<\mathbf{0 . 0 0 1}$ & 12.3 & $<\mathbf{0 . 0 0 1}$ & 11.0 & $<0.001$ & 13.1 & $<\mathbf{0 . 0 0 1}$ \\
\hline
\end{tabular}
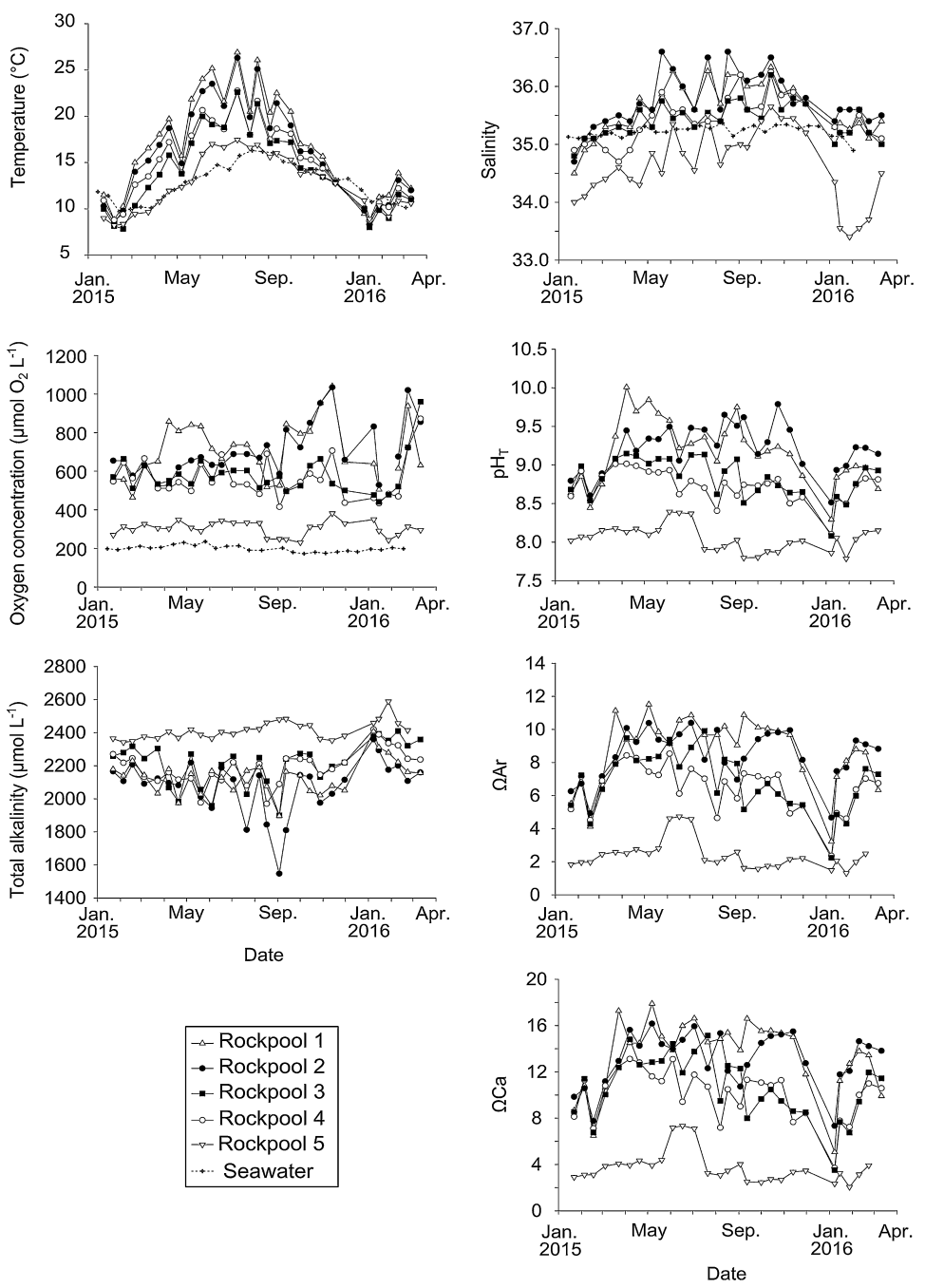

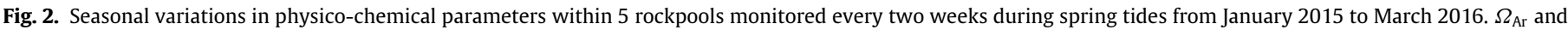

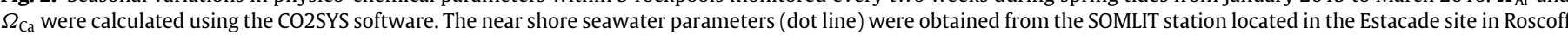
(Brittany, France).

\subsection{Diurnal variations}

Diurnal variations exhibited differences among the 3 rockpools monitored both in the summer 2015 (Fig. 5) and the winter 2016 (Fig. 6). While rockpool 1 presented high variations for all physicochemical parameters, variations in rockpool 5 were close to those of nearshore seawater. Furthermore, higher diurnal amplitudes were observed in the summer for all parameters, except for salinity for which variations are greater in winter. In the winter, diurnal temperature in rockpool 2 varied from $7.2{ }^{\circ} \mathrm{C}$ to $12.0^{\circ} \mathrm{C}$ at the end of night- and day-time emersion, respectively. In the summer, temperature ranged from $13.4^{\circ} \mathrm{C}$ at night to $20.9{ }^{\circ} \mathrm{C}$ at the middle of day-time emersion.

The salinity in rockpools was higher in the summer than in the winter. In the summer, the rockpools 2 and 3 exhibited low salinity variations during night- and day-time emersion. Salinity fluctuations in these rockpools were close to the values of nearshore seawater. Conversely, the rockpool 5 presented higher variations, with a decrease in salinity until 35.0 at the end of the emersion period. Oxygen concentrations during night-time emersion reached minimum concentrations in rockpool 2, at 53 and 10 $\mu \mathrm{mol} \mathrm{O} \mathrm{L}^{-1}$ in the winter and the summer, respectively. During the day-time emersion, maximum oxygen concentrations were measured in rockpool 3 in winter $\left(913 \mu \mathrm{mol} \mathrm{O}_{2} \mathrm{~L}^{-1}\right.$ after $6 \mathrm{~h}$ of emersion) and rockpool 2 in summer ( $955 \mu \mathrm{mol} \mathrm{O}_{2} \mathrm{~L}^{-1}$ after $2 \mathrm{~h}$ of emersion). In rockpool 5, variations in oxygen concentration were lower than in other rockpools. A reduction in oxygen concentration was observed during the day-time emersion in the summer. As for oxygen concentration, $\mathrm{pH}_{\mathrm{T}}$ was constantly reduced at night down to a minimum value was reached in rockpool 2 at the end of the 

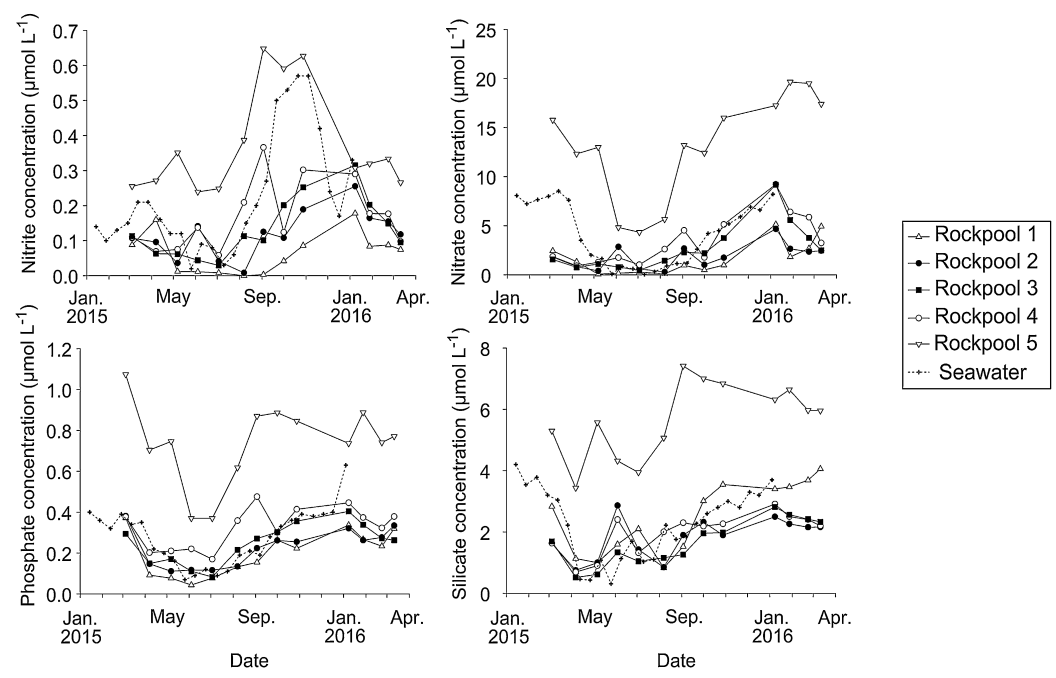

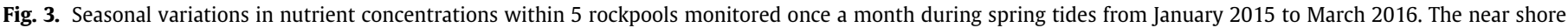
seawater parameters (dot line) were obtained from the SOMLIT station located in the Estacade site in Roscoff (Brittany, France).

a

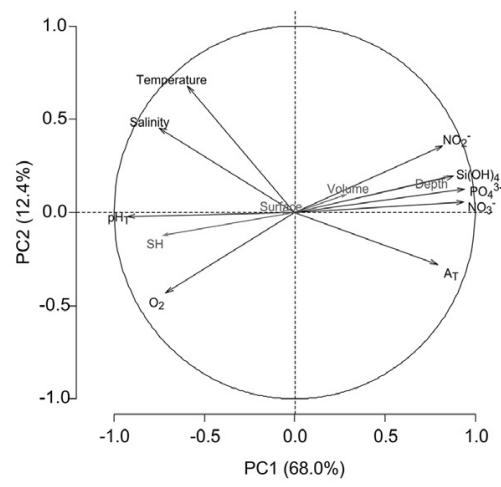

b

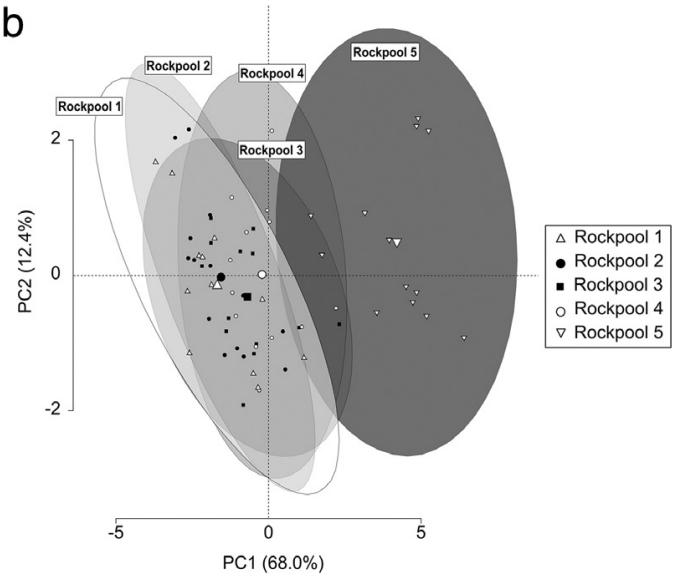

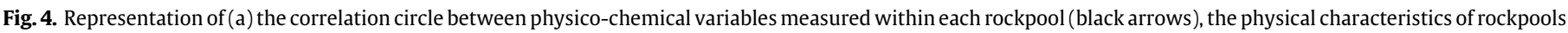
(gray arrows; SH: shore height) and the two principal components and (b) contribution of the space-time measurements to the two principal components.

emersion period (7.57 and 7.49 in the winter and the summer, respectively). During the day, maximal $\mathrm{pH}_{\mathrm{T}}$ values of 9.14 in the winter and 9.90 in the summer were also reached in rockpool 2. Conversely, the rockpool 5 presented low diurnal $\mathrm{pH}_{\mathrm{T}}$ variations

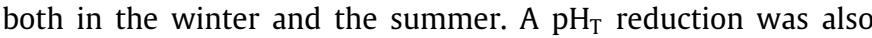
observed during the day-time emersion in the summer. In the winter, $A_{\mathrm{T}}$ increased at night in rockpool 2 only (maximum of $2566 \mu \mathrm{mol} \mathrm{L}^{-1}$ ), while in the summer the rise in $A_{\mathrm{T}}$ was observed within the 3 rockpools monitored. During the day-time emersion, $A_{\mathrm{T}}$ was strongly reduced in rockpools 2 and 3 for each season, with extremely low values reached in rockpool 2 in summer $(1553 \mu \mathrm{mol}$ $\left.\mathrm{L}^{-1}\right)$. As for other parameters, $A_{\mathrm{T}}$ presented weak variations in rockpool 5. The carbonate saturation state with respect to aragonite $\left(\Omega_{\mathrm{Ar}}\right)$ and calcite $\left(\Omega_{\mathrm{Ca}}\right)$ decreased at night in the 3 rockpools monitored, for each season. During the night-time emersion, $\Omega_{\mathrm{Ar}}$ declined below 1 within rockpools 2 and 3, both in the winter and the summer. Conversely, during the day-time emersion, $\Omega_{\mathrm{Ar}}$ and $\Omega_{\mathrm{Ca}}$ increased significantly in rockpools 2 and 3 . Maximum values of 11 and 17 were reached in rockpool 2 in the summer, for $\Omega_{\mathrm{Ar}}$ and $\Omega_{\mathrm{Ca}}$, respectively. Except in the rockpool 5, in which $\Omega$ variations were close to those of near-shore seawater.

\subsection{Community composition}

Regarding the floral composition, strong differences were observed between rockpools and according to the season (Table 3 ). L. incrustans attained the highest biomasses in rockpools 1 and 3 in winter and summer, respectively. Conversely, higher biomass of E. elongata was recorded within rockpool 5 both in summer and winter. Fleshy algae biomass ranged from $204.5 \mathrm{~g} \mathrm{AFDW} \mathrm{m}^{-2}$ to $712.3 \mathrm{~g} \mathrm{AFDW} \mathrm{m}^{-2}$ in summer (rockpools 2 and 4 , respectively) and from $3.7 \mathrm{~g} \mathrm{AFDW} \mathrm{m}^{-2}$ to $228.0 \mathrm{~g} \mathrm{AFDW} \mathrm{m}^{-2}$ in winter (rockpools 2 and 5 , respectively). In the summer, rockpool 1 was dominated by the green algae Ulva intestinalis and the brown seaweed S. muticum while the rockpool 2 was mainly composed by Ulva sp. In winter, fleshy algae were nearly absent in these two rockpools. S. muticum was the dominant fleshy alga within the rockpool 3 both in the summer and the winter, although winter biomass was only half that of summer biomass. In the rockpool 4, the fleshy algal biomass was lower in winter compared with summer being mainly composed by the brown alga F. serratus. The fleshy algal biomass of rockpool 5 consisted of more diverse and sparse seaweeds. Although Ulva sp. and S. muticum were still abundant in this rockpool, the greater part of summer biomass corresponded to a few small feet of Laminaria digitata. In winter, fleshy algae community was dominated by undetermined filamentous red algae which grew on E. elongata. 
SUMMER
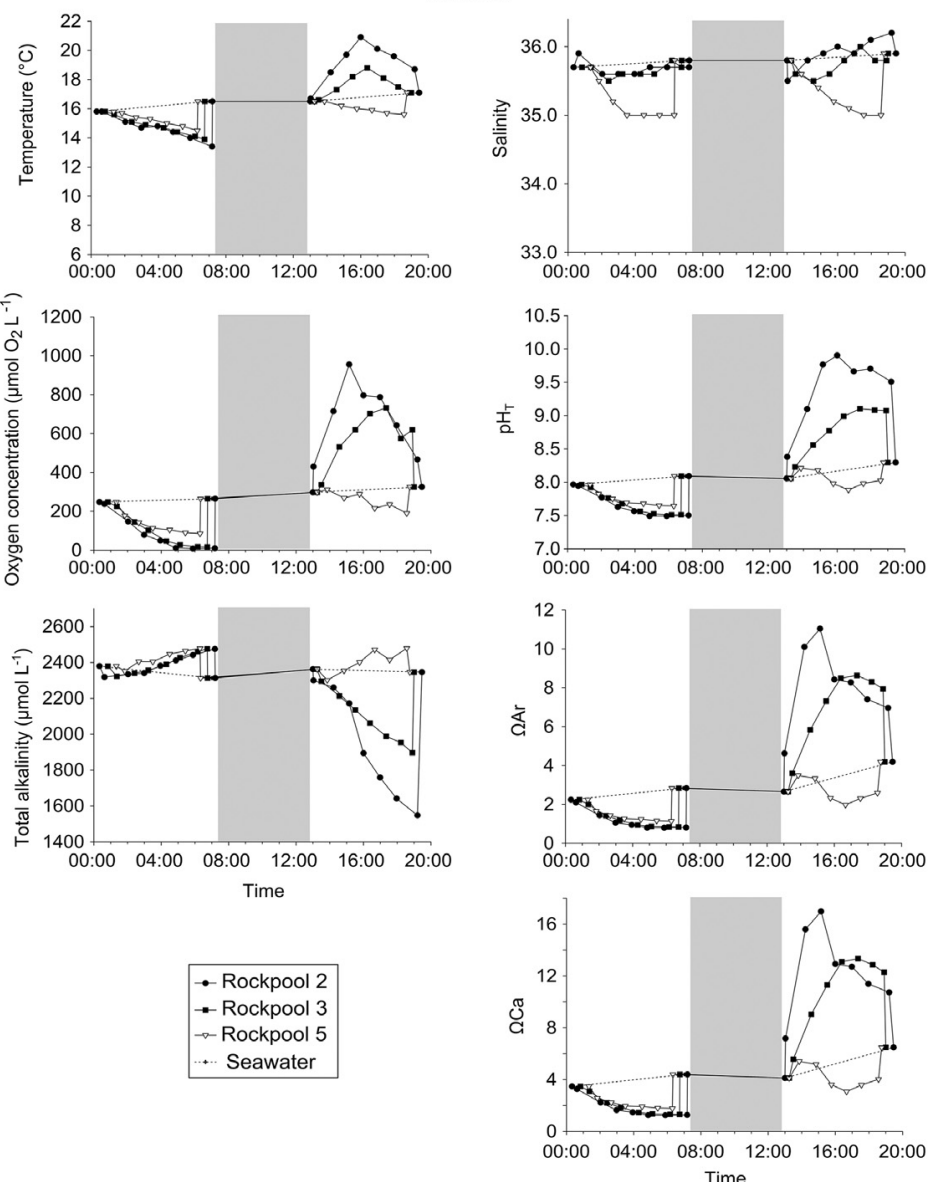

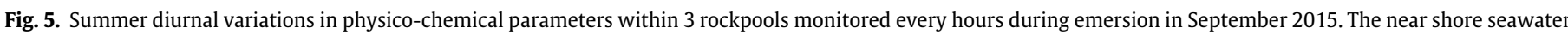

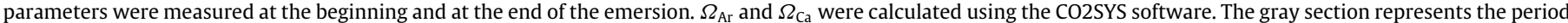
during which all the rockpools were covered by the tide.

Table 3

Winter and summer biomasses (in grams of ash-free dry weight) of the dominant coralline and fleshy algae present in the five rockpools monitored for seasonal variations at the Bloscon site in Roscoff (Brittany, France).

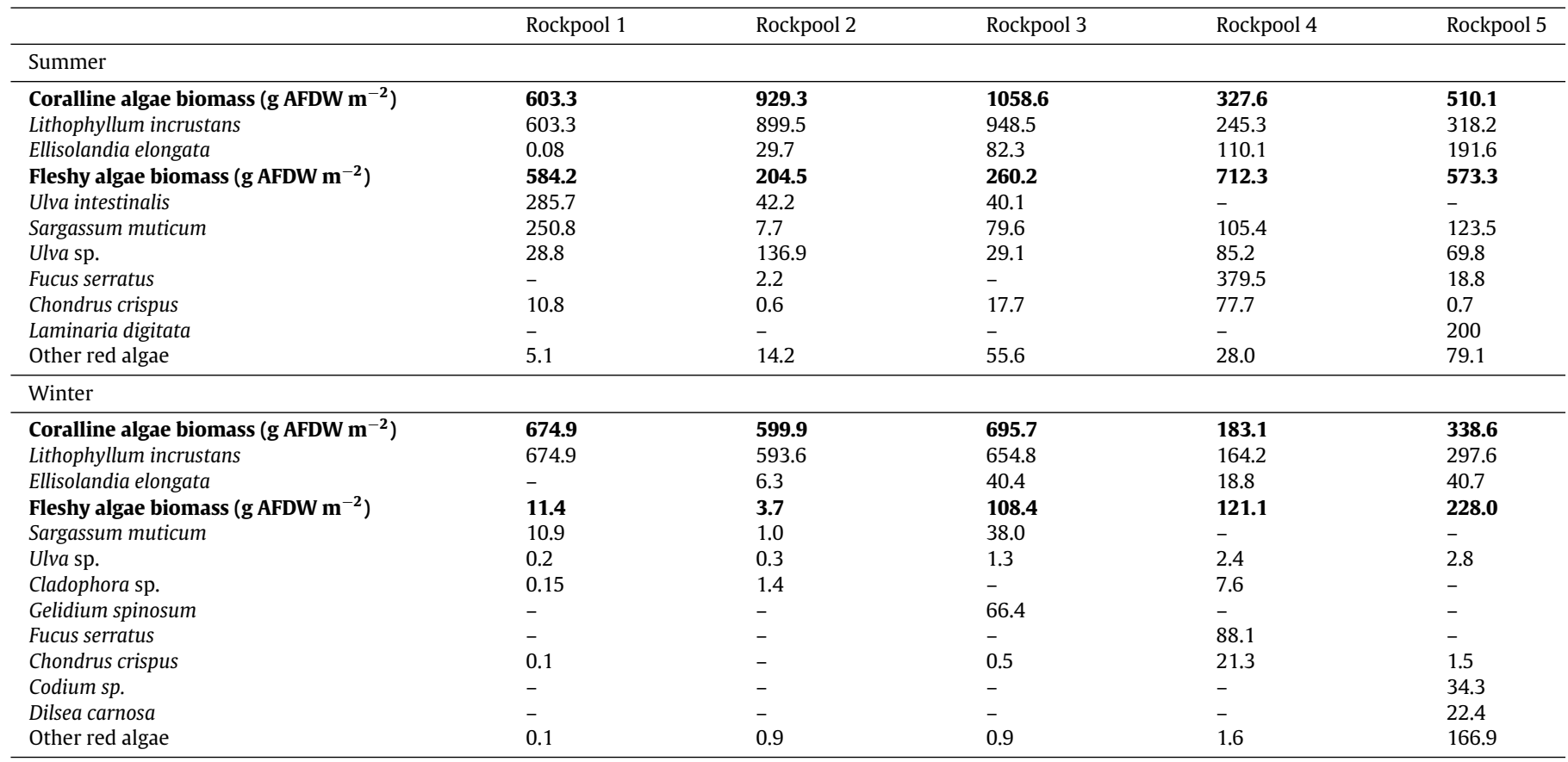



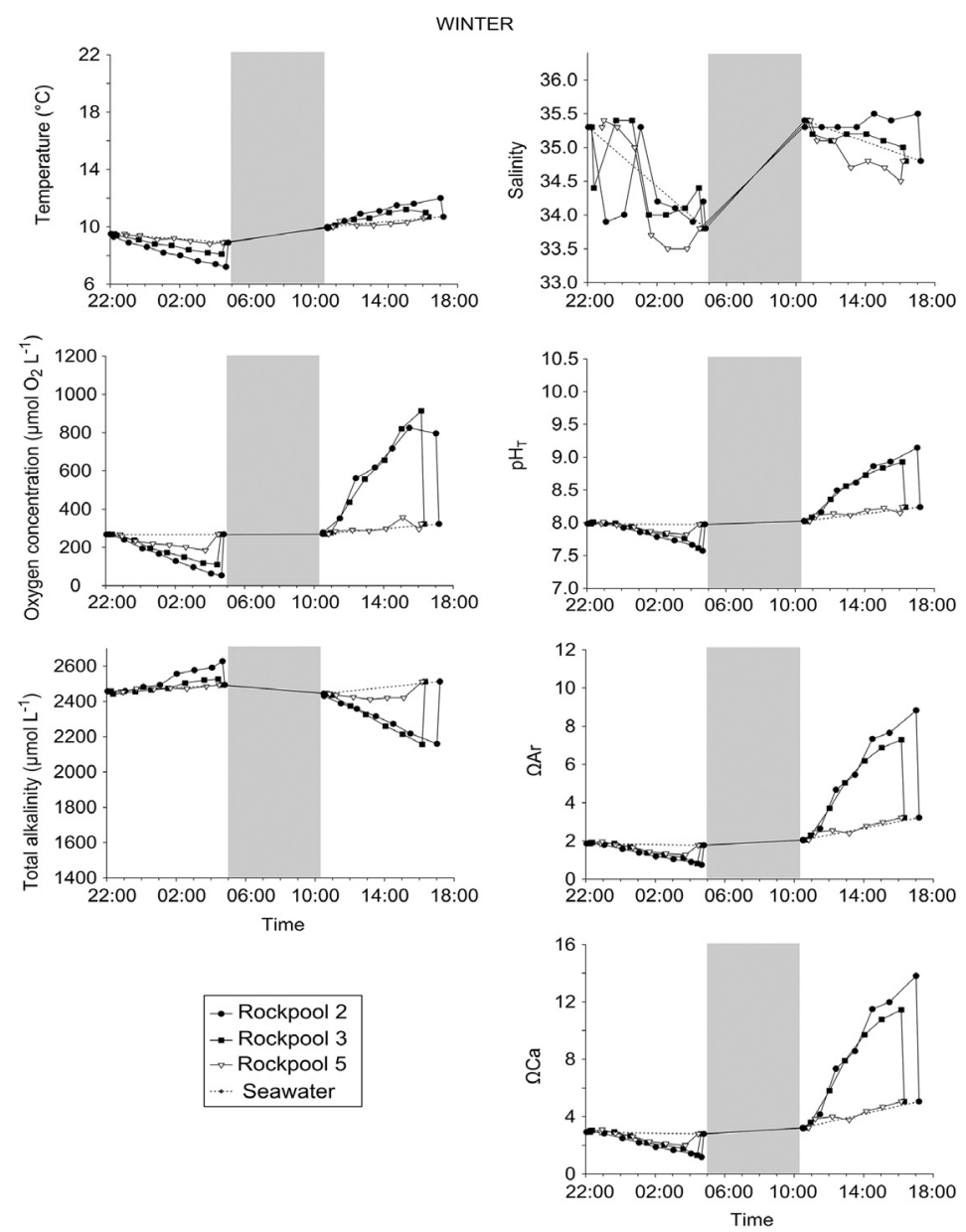

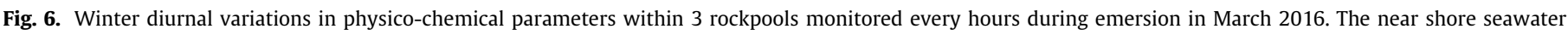

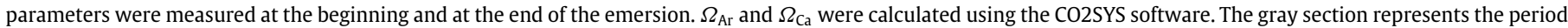
during which all the rockpools were covered by the tide.

The total biomass of fauna ranged from $4.2 \mathrm{~g} \mathrm{AFDW} \mathrm{m}^{-2}$ (rockpool 5) to $11.8 \mathrm{~g} \mathrm{AFDW} \mathrm{m}^{-2}$ (rockpool 4) in summer and from $0.7 \mathrm{~g}$ AFDW m ${ }^{-2}$ (rockpool 1) to $12.4 \mathrm{~g} \mathrm{AFDW} \mathrm{m}^{-2}$ (rockpool 2) in winter. The gastropod Gibbula umbilicalis dominated the faunal species in all the rockpools both in winter and summer. The biomass of $G$. umbilicalis extended from $0.75 \mathrm{~g} \mathrm{AFDW} \mathrm{m}^{-2}$ to $4.14 \mathrm{~g} \mathrm{AFDW} \mathrm{m}^{-2}$ in summer (rockpools 5 and 3, respectively) and from $0 \mathrm{~g}$ AFDW $\mathrm{m}^{-2}$ to $6.1 \mathrm{~g} \mathrm{AFDW} \mathrm{m}^{-2}$ in winter (rockpools 4 and 2, respectively).

\section{Discussion}

Rockpool environment is governed by complex interactions between physical, chemical and biological parameters (Martins et al., 2007). Rockpools can be described by evaluating their shore height, surface, depth and volume. Among these characteristics, shore height appeared as one of the main physical factors controlling the physico-chemical variability within rockpools, as evidenced by Morris and Taylor (1983). Consistently with their findings, rockpools 1 and 2 located on the upper shore exhibited the largest diurnal and seasonal fluctuations of temperature, oxygen and $\mathrm{pH}_{\mathrm{T}}$. In contrast, the rockpool 5 was the lowest on the shore and the deepest and presented weaker variations in temperature, oxygen and $\mathrm{pH}_{\mathrm{T}}$ but higher nutrient concentrations and total alkalinity. In accordance with the present results, Martins et al. (2007) suggested that rockpools depth was more important in controlling physico-chemical variability than surface and volume.

During the day, upper shore rockpools were directly exposed to incident light, increasing the seawater temperature. Moreover, rockpools higher on the shore zone are exposed to external conditions for longer than lower ones, increasing the duration of thermic exchange with the atmosphere (Martins et al., 2007). This results in larger diurnal and seasonal variations in temperature than in lower shore rockpools. Similarly at night, the temperature within rockpools was mainly driven by the atmospheric temperature and wind exposure. In both the winter and the summer, atmospheric temperature at night was lower than near-shore seawater. As a consequence, during the emersion period, the temperature decrease at night was more important in high shore rockpools. In contrast to the upper shore rockpools, lower shore rockpools presented lower seasonal and diurnal variations for all parameters, except for salinity and nutrients. The salinity showed seasonal variability, with higher values in the summer, when evaporation was maximal. However, freshwater seepage may occur within the rockpool 5, as the salinity in this rockpool was lower than near-shore seawater both for seasonal and diurnal measurements. This statement is in accordance with the higher nutrient values measured in this rockpool.

As for intertidal emerging substrate, light intensity and temperature exert a strong influence on biological processes (Fernández et al., 2015; Martínez et al., 2012). Indeed, rockpool communities undergo a wide range of irradiance, determined by the seasonal, daily and tide cycles, and the cloud cover (Figs. 7 and 8; Häder et al., 2003). In the present study, the CCA L. incrustans colonized all rockpools, but reached the highest biomass in shallow high shore rockpools, both in the winter and the summer. This suggested that this species was stress-tolerant and was able to withstand high 


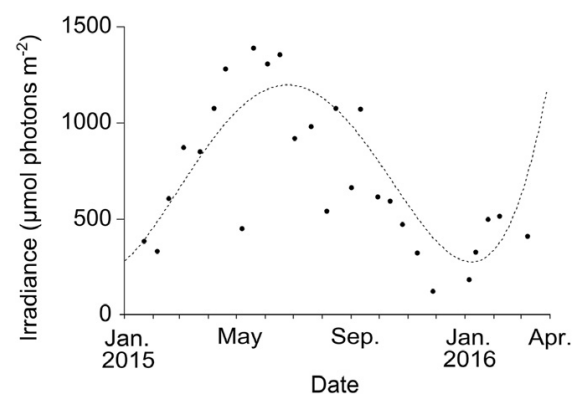

Fig. 7. Seasonal variations in light intensity measured at noon in air at the Station Biologique de Roscoff from January 2016 to April 2016 (dot line). Black dots represent the mean irradiance measured in air during day-time emersion for each seasonal measurement.

temperatures and light intensities (Dethier, 1994; Kooistra et al., 1989). Conversely, the articulated coralline algae E. elongata attained higher biomass within deeper and shaded rockpools. Egilsdottir et al. (2016) related a strong inhibition of photosynthesis and calcification in E. elongata under irradiances beyond $200 \mu \mathrm{mol}$ photons $\mathrm{m}^{-2} \mathrm{~s}^{-1}$ in the summer. In the present study, E. elongata was almost absent from upper shore rockpools, where incident light intensity reached up to 800 and $1600 \mu \mathrm{mol}$ photons $\mathrm{m}^{-2}$ $\mathrm{s}^{-1}$ in the winter and the summer, respectively (Fig. 8). Hence, conversely to L. incrustans, E. elongata may tolerate lower light intensities (Egilsdottir et al., 2016; Korbee et al., 2014) and may benefit from the shaded environment provided by deeper and sheltered rockpools.

In the summer, shallow upper shore rockpools were dominated by Ulva intestinalis and Ulva sp., respectively, although Sargassum muticum was co-dominant within the rockpool 1 . Ulva is a cosmopolitan genus in intertidal environments, especially rockpools, and is characterized by a strong ability to cope with changing light conditions and tolerate high light intensities (Altamirano et al., 2000; Gómez et al., 2004; Ruangchuay et al., 2012). S. muticum was the dominant canopy-forming species in the rockpool 3. As for Ulva sp., Norton (1977) demonstrated that S. muticum have a broad tolerance for irradiance, salinity and temperature.

Within the rockpool 4, a dense canopy of the brown algae Fucus serratus was observed both in the winter and the summer. Thus, rockpools 1 to 4 are covered by a dense canopy of $U$. intestinalis, $S$. muticum and/or F. serratus from spring to late summer, when light intensities are high. Olabarria et al. (2013) highlighted the importance of canopy composition for understory species. For most intertidal seaweeds, the high light intensities in the summer often greatly exceed their needs for photosynthesis (Franklin and Forster, 1997). Although photoinhibition may affect these canopyforming species, they are also likely to act as a protective layer for understory species, which may benefit from reduced light stress for their metabolic activity (Bordeyne et al., 2015; Tait and Schiel, 2011). In the summer, $L$. incrustans and E. elongata would thus be protected from photoinhibition by the dense canopy formed by $U$. intestinalis, S. muticum and F. serratus. This statement may be consistent with the bleaching observed in E. elongata when colonizing rockpool edges without canopy (personal observation). The bleaching in coralline algae under high irradiances has already been reported by Häder et al. (2003).

Communities inhabiting rockpools also exerted a strong influence on the physico-chemical variations. During the day-time emersion, a part of incident light was used by seaweeds for their photosynthesis, reducing inorganic carbon and nutrients in the seawater during the emersion period and increasing oxygen concentrations. Ulva spp. are known to have a high plasticity in utilizing different forms of inorganic carbon through the use of powerful carbon concentration mechanisms (CCM; Axelsson et al., 1999; Axelsson et al., 1995; Rautenberger et al., 2015).
This process may confer a competitive advantage to Ulva spp., especially when $\mathrm{CO}_{2}$ is limited (Axelsson et al., 1995; Larsson et al., 1997). Similarly, the ability of S. muticum to use bicarbonates $\left(\mathrm{HCO}_{3}^{-}\right)$through $\mathrm{CCM}$ makes it unlikely to be limited in $\mathrm{CO}_{2}$ for its photosynthesis (Thomas and Tregunna, 1968). Interestingly, no clear seasonal trend was measured in rockpools in terms of oxygen concentrations. Within upper shore rockpools, oxygen concentration varied greatly throughout the year with a peak detected in November, although light intensities were reduced compared with the summer. Several explanations could be provided: (1) the high light intensities in summer induce photoinhibition in seaweeds colonizing shallow and high shore rockpools, limiting oxygen concentration increase (Egilsdottir et al., 2016; Häder et al., 2003; Raven and Hurd, 2012). (2) The high photosynthetic rates combined with the important canopy biomass in summer severely reduced the nutrients which rapidly became limiting for seaweed primary production (Henley et al., 1991; Metaxas et al., 1994). In the autumn, the highest nutrient availability and the lowest light intensities may increase photosynthesis and oxygen release in rockpools. Oxygen concentration within the lower shore rockpool was more stable during the year than in other rockpools, with concentrations close to those of near-shore seawater. This rockpool was more shaded than other rockpools due to the presence of high surrounding rocks. Although nutrient concentrations were higher, the lower incident light may limit the community production.

During the night-time emersion, the community respiration decreased the oxygen concentration in the three rockpools monitored, both in the winter and the summer. However, the higher seaweed biomass in the summer reduced drastically oxygen concentrations, especially within rockpools 2 and 3. The higher temperature in the summer at night may increase the metabolic rates of rockpool communities (Tagliarolo et al., 2013; Zou et al., 2007) reducing oxygen concentration more severely. A plateau was reached from 4 am in these two rockpools, which became almost anoxic at the end of the night-time emersion. Conversely, in the winter, the decrease in oxygen concentration at night was more linear until the end of the night-time emersion. Temperature also influences gas solubility, and Truchot and Duhamel-Jouve (1980) suggested that the increase in oxygen concentration during the day and the decrease at night may be limited by diffusion process across the air-water interface.

By their photosynthesis, seaweeds also reduced the carbon dioxide $\left(\mathrm{CO}_{2}\right)$ concentration in the rockpools during the emersion period. As consequence, the $\mathrm{pH}_{\mathrm{T}}$ of seawater increased, and reached 10 in spring in the rockpool 1, during the bloom of Ulva intestinalis, consistent with the results of Björk et al. (2004) for isolated rockpools in Sweden. A peak of $\mathrm{pH}_{\mathrm{T}}$ was also observed in November in the rockpool 2, which corresponded to the maximum oxygen concentration in this rockpool. Conversely, at night, the community respiration during emersion increased the $\mathrm{CO}_{2}$ concentrations and reduced the $\mathrm{pH}_{\mathrm{T}}$ down to 7.5. The important seaweed biomass in the summer and the high respiration at night severely decreased the $\mathrm{pH}_{\mathrm{T}}$ until a plateau was reached when oxygen has been consumed.

The variations in $\mathrm{pH}_{\mathrm{T}}$ have a strong influence on the carbonate saturation state with respect to aragonite $\left(\Omega_{\mathrm{Ar}}\right)$ and calcite $\left(\Omega_{\mathrm{Ca}}\right)$. In marine systems, the equilibrium between the different inorganic carbon species is a major factor influencing the calcification process (Borowitzka and Larkum, 1987). $\Omega$ defines the ability of calcareous species to produce their skeleton, through the precipitation of calcium carbonate $\left(\mathrm{CaCO}_{3}\right)$ (Kleypas et al., 2006; Raven, 2011). The relationship between saturation state values and coralline calcification and growth is well known (Kuffner et al., 2008). Despite the presence of seasonal variations, $\Omega$ was much greater than 1 in upper shore rockpools during the day-time emersion, making the environment more conducive to calcification. In 

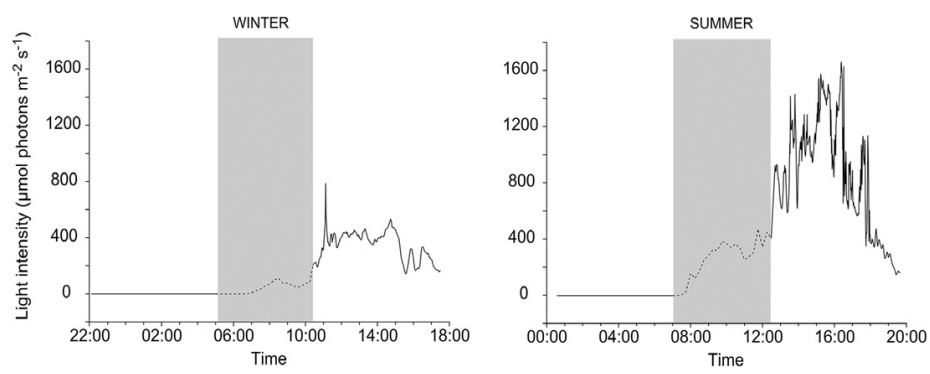

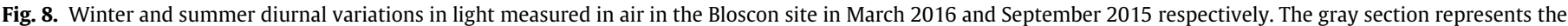
period during which all the rockpools were covered by the tide. Irradiance during immersion was estimated using extinction coefficient of light in seawater.

the lower shore rockpool, $\Omega_{\mathrm{Ar}}$ and $\Omega_{\mathrm{Ca}}$ reached values close to 1 in January which suggests a lower potential for calcareous species to calcify in winter during day-time emersion.

Several studies underlined the interaction between photosynthesis and calcification processes in coralline algae (Comeau et al., 2012; McCoy et al., 2016). The "trans calcification" process described by McConnaughey and Whelan (1997) suggests that calcareous algae may uptake seawater $\mathrm{HCO}_{3}^{-}$and convert it to $\mathrm{CO}_{2}$ thanks to proton transport through the organism. A part of this $\mathrm{CO}_{2}$ would be used for algal photosynthesis while another part would be converted to produce $\mathrm{CO}_{3}^{2-}$ used for calcification. Although this process was evidenced in the freshwater alga Chara corallina (McConnaughey and Whelan, 1997), "trans calcification" may also occur in geniculate coralline algae (McCoy et al., 2016) and L. incrustans. Within rockpools, where $\mathrm{CO}_{2}$ concentrations may be low during the day, this mechanism may provide sufficient inorganic carbon substrate to increase both photosynthetic and calcification rates. This statement would be consistent with the decrease in $A_{\mathrm{T}}$ observed during the day-time emersion in the summer within upper shore rockpools. Temperature increase in the summer may also have a positive effect on calcification and growth rates of coralline algae (Martin et al., 2006; Steller et al., 2007). Finally, a part of the calcification can also be attributed to calcareous fauna, since (Tagliarolo et al., 2013) highlighted an increase in calcification rates in summer in several intertidal gastropods, including G. umbilicalis.

E. elongata is known to have high calcification rates, with a light to dark ratio of 3.6 (El Haikali et al., 2004). In a recent study, Egilsdottir et al. (2016) estimated that calcification in E. elongata on the north coast of Brittany was $3.3 \mu \mathrm{mol} \mathrm{CaCO}_{3} \mathrm{~g} \mathrm{DW}^{-1} \mathrm{~h}^{-1}$ in the summer and $1.1 \mu \mathrm{mol} \mathrm{CaCO} \mathrm{g} \mathrm{DW}^{-1} \mathrm{~h}^{-1}$ in the winter. During night-time emersion, the increase in $A_{\mathrm{T}}$ reflected the dissolution of coralline algae, explained by the decline of $\mathrm{pH}_{\mathrm{T}}$ and $\Omega$. This suggests that the increase in dissolution rates during night-time emersion would be offset by high calcification rates during the daytime emersion. In a Mediterranean shallow infralittoral ecosystem dominated by E. elongata, Bensoussan and Gattuso (2007) also evidenced strong diurnal variations, with higher calcification rates when light intensities were maximal. In the present study, biomass of E. elongata reached $982 \mathrm{~g} \mathrm{DW} \mathrm{m}^{-2}$ in rockpool 5. This value is lower than those reported for infralittoral communities on the Costa Brava (1110 to $4015 \mathrm{~g} \mathrm{DW} \mathrm{m}^{-2}$; Ballesteros, 1988), but is close to the lower values reported by El Haikali et al. (2004) on the Gulf of Marseilles ( 820 to $2544 \mathrm{~g} \mathrm{DW} \mathrm{m}^{-2}$ ). Moreover, in south-west Wales, Edyvean and Ford (1987) evidenced that $\mathrm{CaCO}_{3}$ deposition rate for L. incrustans was $378.96 \mathrm{~g} \mathrm{~m}^{-2}$ plant surface area year $^{-1}$. Within rockpools, many factors may influence the calcification rates in coralline algae, such as rockpools exposition to incident light, the seawater physico-chemical parameters, but also the interaction with other species. However, the present results evidence that coralline algae colonizing rockpools can be considered as a key element of carbonate cycles in the shallow coastal waters.
This study provides evidence that although seaweeds were likely to strongly influence physico-chemical variations in rockpools, these variations were also governed by more complex interactions between physical parameters of rockpools (e.g. shore height, depth, light exposure, temperature...), chemical processes (gas exchange between the seawater and the atmosphere, interaction between physico-chemical parameters) and biotic factors (metabolic processes of species, nutrient/light limitation). Rockpools can thus be considered as complex dynamic environments, unique in their functioning due to the large number of interactions between physical, chemical and biological factors.

Within rockpools, physico-chemical variations mainly depend on their depth and the duration of their isolation from the sea during low tide. Seaweed species colonizing rockpools can thus survive harsh environmental conditions, such as low oxygen concentration and $\mathrm{pH}_{\mathrm{T}}$ at night or high temperature and low nutrient concentrations during the day. However, species require a regular exchange of seawater for regulating physico-chemical parameters and recover from the emersion period. In coralline algae, low $\mathrm{pH}_{\mathrm{T}}$ and carbonate saturation state at night may have deleterious consequences on their calcareous skeleton by increasing dissolution (Comeau et al., 2012; Egilsdottir et al., 2016).

The present study evidenced that rockpool organisms undergo physico-chemical variations that may greatly exceed those predicted with climate change for the end of the century (Gattuso et al., 2015). However, few studies took into account both emersion variability and inter-specific interactions (Olabarria et al., 2013). Regarding climate change experiments, particular attention should be paid to the natural variability that tested species undergo. Therefore, rockpools appear as suitable environments to examine the physiological processes set up by species to face natural variability.

\section{Acknowledgments}

The authors thank Jérôme Coudret, Stéphane Loisel, Marine Macé, Robin Marsac, Doriane Stagnol, Aline Migné and Louis Girard for their field assistance. We also thank the SOMLIT (Service d'Observation en Milieu LITtoral, INSU-CNRS) program for the temperature data sets provided. This work was supported by the Brittany Regional Council and the French National Research Agency via the "Investment for the Future" program IDEALG ( $n^{\circ}$ ANR-10BTBR-04).

\section{References}

Altamirano, M., Flores-Moya, A., Figueroa, F.L., 2000. Long-term effects of natural sunlight under various ultraviolet radiation conditions on growth and photosynthesis of intertidal Ulva rigida (Chlorophyceae) cultivated in situ. Bot. Mar. 43, 119-126.

Aminot, A., Kérouel, R., 2007. Dosage automatique des nutriments dans les eaux marines: méthodes en flux continu. Ifremer, MEDD, Quae.

Anderson, M.J., 2001. A new method for non-parametric multivariate analysis of variance. Austral Ecol. 26, 32-46 
Araujo, R., Sousa-Pinto, I., Barbara, I., Quintino, V., 2006. Macroalgal communities of intertidal rock pools in the northwest coast of Portugal. Acta Oecol. 30,192-202.

Axelsson, L., Larsson, C., Ryberg, H., 1999. Affinity, capacity and oxygen sensitivity of two different mechanisms for bicarbonate utilization in Ulva lactuca L. (Chlorophyta). Plant Cell Environ. 22, 969-978.

Axelsson, L., Ryberg, H., Beer, S., 1995. Two modes of bicarbonate utilization in the marine green macroalga Ulva lactuca. Plant Cell Environ. 18, 439-445.

Ballesteros, E., 1988. Composición y estructura de la comunidad infralitoral de Corallina elongata Ellis \& Solander, 1786, de la Costa Brava (Mediterráneo occidental). Invest. Pesq. 52, 135-151.

Benedetti-Cecchi, L., Bulleri, F., Cinelli, F., 2000. The interplay of physical and biological factors in maintaining mid-shore and low-shore assemblages on rocky coasts in the north-west Mediterranean. Oecologia 123, 406-417.

Bensoussan, N., Gattuso, J.-P., 2007. Community primary production and calcification in a NW Mediterranean ecosystem dominated by calcareous macroalgae. Mar. Ecol. Prog. Ser. 334, 37-45.

Björk, M., Axelsson, L., Beer, S., 2004. Why is Ulva intestinalis the only macroalga inhabiting isolated rockpools along the Swedish Atlantic coast? Mar. Ecol. Prog. Ser. 284, 109116.

Bordeyne, F., Migné, A., Davoult, D., 2015. Metabolic activity of intertidal Fucus spp. communities: evidence for high aerial carbon fluxes displaying seasonal variability. Mar. Biol. 162, 2119-2129.

Borowitzka, M.A., Larkum, A.W.D., 1987. Calcification in algae: Mechanisms and the role of metabolism. Crit. Rev. Plant Sci. 6, 1-45.

Collén, J., Davison, I.R., 1999. Reactive oxygen metabolism in intertidal Fucus spp. (Phaeophyceae). J. Phycol. 35, 62-69.

Comeau, S., Carpenter, R.C., Edmunds, P.J., 2012. Coral reef calcifiers buffer their response to ocean acidification using both bicarbonate and carbonate. Proc. Roy. Soc. B: Biol. Sci. 280, 20122374

Crisp, D.J., 1984. Energy flow measurements. In: Holme, N.A., McIntyre, A.D. (Eds.), Methods for the Study of Marine Benthos. Blackwell, Oxford, pp. 197-279.

Daniel, M., Boyden, C., 1975. Diurnal variations in physico-chemical conditions within intertidal rockpools. Field Stud. 4, 161-176.

Dethier, M.N., 1994. The ecology of intertidal algal crusts: Variation within a functional group. J. Exp. Mar. Biol. Ecol. 177, 37-71.

Dickson, A.G., Millero, F.J., 1987. A comparison of the equilibrium constants for the dissociation of carbonic acid in seawater media. Deep Sea Res. 34, 1733-1743.

Dickson, A.G., Sabine, C.L., Christian, J.R., 2007. Guide to Best Practices for Ocean $\mathrm{CO}_{2}$ Measurements. In: PICES Special Publication, North Pacific Marine Science Organization, Sidney, British Columbia, p. 176.

Edyvean, R.G.J., Ford, H., 1987. Growth rates of Lithophyllum incrustans (Corallinales, Rhodophyta) from South West Wales. Br. Phycol. J. 22, 139-146.

Egilsdottir, H., Olafsson, J., Martin, S., 2016. Photosynthesis and calcification in the articulated coralline alga Ellisolandia elongata (Corallinales, Rhodophyta) from intertidal rock pools. Eur. J. Phycol. 51, 59-70.

El Haikali, B., Bensoussan, N., Romano, J.C., Bousquet, V., 2004. Estimation of photosynthesis and calcification rates of Corallina elongata Ellis and Solander, 1786, by measurements of dissolved oxygen, $\mathrm{pH}$ and total alkalinity. Sci. Mar. 68, 45-56.

Fernández, Á., Arenas, F., Trilla, A., Rodríguez, S., Rueda, L., Martínez, B., 2015. Additive effects of emersion stressors on the ecophysiological performance of two intertidal seaweeds. Mar. Ecol. Prog. Ser. 536, 135-147.

Firth, L.B., Schofield, M., White, F.J., Skov, M.W., Hawkins, S.J., 2014. Biodiversity in intertidal rock pools: Informing engineering criteria for artificial habitat enhancement in the built environment. Mar. Environ. Res. 102, 122-130.

Firth, L.B., Thompson, R.C., White, F.J., Schofield, M., Skov, M.W., Hoggart, S.P.G., Jackson, J., Knights, A.M., Hawkins, S.J., 2013. The importance of water-retaining features for biodiversity on artificial intertidal coastal defence structures. Divers. Distrib. 19, $1275-1283$.

Franklin, L.A., Forster, R.M., 1997. The changing irradiance environment: consequences for marine macrophyte physiology, productivity and ecology. Eur. J. Phycol. 32, $207-$ 232 .

Ganning, B., 1971. Studies on chemical, physical and biological conditions in Swedish rockpool ecosystems. Ophelia 9, 51-105.

Gattuso, J.P., Magnan, A., Billé, R., Cheung, W.W.L., Howes, E.L., Joos, F., Allemand, D., Bopp, L., Cooley, S.R., Eakin, C.M., Hoegh-Guldberg, O., Kelly, R.P., Pörtner, H.O., Rogers, A.D., Baxter, J.M., Laffoley, D., Osborn, D., Rankovic, A., Rochette, J., Sumaila, U.R. Treyer, S., Turley, C., 2015. Contrasting futures for ocean and society from different anthropogenic $\mathrm{CO}_{2}$ emissions scenarios. Science 349,1-10.

Gómez, I., López-Figueroa, F., Ulloa, N., Morales, V., Lovengreen, C., Huovinen, P., Hess, S., 2004. Patterns of photosynthesis in 18 species of intertidal macroalgae from southern Chile. Mar. Ecol. Prog. Ser. 270, 103-116.

Häder, D.-P., Lebert, M., Walter Helbling, E., 2003. Effects of solar radiation on the patagonian rhodophyte Corallina officinatis (L.). Photosynth. Res. 78, 119-132.

Henley, W.J., Levavasseur, G., Franklin, L.A., Osmond, C.B., Ramus, J., 1991 Photoacclimation and photoinhibition in Ulva rotundata as influenced by nitrogen availability. Planta 184, 235-243.

Hoffman, J.R., Hansen, L.J., Klinger, T., 2003. Interactions between UV radiation and temperature limit inferences from single-factor experiments. J. Phycol. 39,268-272.

Huggett, J., Griffiths, C.L., 1986. Some relationships between elevation, physicochemical variables and biota of intertidal rock pools. Mar. Ecol. Prog. Ser. 29, 189-197.

Kleypas, J.A., Feely, R.A., Fabry, V.J., Langdon, C., Sabine, C.L., Robbins, L.L., 2006. Impacts of ocean acidification on coral reefs and other marine calcifiers: a guide for future research, Report of a workshop held, April 18-20, 2005, NSF, NOAA, and the US Geological Survey, St. Petersburg, FL, USA, p. 88
Kooistra, W.H.C.F., Joosten, A.M.T., van den Hoek, C., 1989. Zonation patterns in intertidal pools and their possible causes: a multivariate approach. Bot. Mar. 32, 9-26.

Korbee, N., Navarro, N.P., Garcia-Sanchez, M., Celis-Pla, P.S.M., Quintano, E., Copertino, M.S., Pedersen, A., Mariath, R., Mangaiyarkarasi, N., Perez-Ruzafa, A., Figueroa, F.L. Martinez, B., 2014. A novel in situ system to evaluate the effect of high $\mathrm{CO}_{2}$ on photosynthesis and biochemistry of seaweeds. Aquatic Biol. 22, 245-259.

Kuffner, I.B., Andersson, A.J., Jokiel, P.L., Rodgers, K.S., Mackenzie, F.T., 2008. Decreased abundance of crustose coralline algae due to ocean acidification. Nat. Geosci. 1, 114117.

Larsson, C., Axelsson, L., Ryberg, H., Beer, S., 1997. Photosynthetic carbon utilization by Enteromorpha intestinalis (Chlorophyta) from a Swedish rockpool. Eur. J. Phycol. 32, 49-54.

Lewis, E., Wallace, D.W.R., 1998. Program developed for $\mathrm{CO}_{2}$ system calculations. Carbon dioxide information analysis center, Oak Ridge National Laboratory, U.S. Department of Energy.

Martin, S., Castets, M.D., Clavier, J., 2006. Primary production, respiration and calcification of the temperate free-living coralline alga Lithothamnion corallioides. Aquat Bot. 85 121-128.

Martínez, B., Arenas, F., Rubal, M., Burgués, S., Esteban, R., García-Plazaola, I., Figueroa, F.L., Pereira, R., Saldaña, L., Sousa-Pinto, I., Trilla, A., Viejo, R.M., 2012. Physical factors driving intertidal macroalgae distribution: physiological stress of a dominant fucoid at its southern limit. Oecologia 170, 341-353.

Martins, G.M., Hawkins, S.J., Thompson, R.C., Jenkins, S.R., 2007. Community structure and functioning in intertidal rock pools: effects of pool size and shore height at different successional stages. Mar. Ecol. Prog. Ser. 329, 43-55.

McConnaughey, T.A., Whelan, J.F., 1997. Calcification generates protons for nutrient and bicarbonate uptake. Earth-Sci. Rev. 42, 95-117.

McCoy, S.J., Pfister, C.A., Olack, G., Colman, A.S., 2016. Diurnal and tidal patterns of carbon uptake and calcification in geniculate inter-tidal coralline algae. Mar. Ecol. 37, 553564.

Mehrbach, C., Culberso. Ch, Hawley, J.E., Pytkowic, R.M., 1973. Measurement of apparent dissociation-constants of carbonic-acid in seawater at atmospheric-pressure. Limnol. Oceanogr. 18, 897-907.

Metaxas, A., Hunt, H.L., Scheibling, R.E., 1994. Spatial and temporal variability of macrobenthic communities in tidepools on a rocky shore in Nova-Scotia, Canada. Mar. Ecol. Prog. Ser. 105, 89-103.

Metaxas, A., Scheibling, R.E., 1993. Community structure and organization of tidepools Mar. Ecol. Prog. Ser. 98, 187-198.

Morris, S., Taylor, A.C., 1983. Diurnal and seasonal variation in physicochemical conditions within intertidal rock pools. Estuar. Coast. Shelf Sci. 17, 339-355.

Norton, T.A., 1977. The growth and development of Sargassum muticum (Yendo) Fensholt J. Exp. Mar. Biol. Ecol. 26, 41-53.

Olabarria, C., Arenas, F., Viejo, R.M., Gestoso, I., Vaz-Pinto, F., Incera, M., Rubal, M., Cacabelos, E., Veiga, P., Sobrino, C., 2013. Response of macroalgal assemblages from rockpools to climate change: effects of persistent increase in temperature and $\mathrm{CO}_{2}$ Oikos 122, 1065-1079.

Rautenberger, R., Fernández, P.A., Strittmatter, M., Heesch, S., Cornwall, C.E., Hurd, C.L. Roleda, M.Y., 2015. Saturating light and not increased carbon dioxide under ocean acidification drives photosynthesis and growth in Ulva rigida (Chlorophyta). Ecol. Evol. 5, 874-888.

Raven, J.A., 2011. Effects on marine algae of changed seawater chemistry with increasing atmospheric $\mathrm{CO}_{2}$. Biol. Environ.-Proc. R. Ir. Acad. 111B, 1-17.

Raven, J.A., Hurd, C.L., 2012. Ecophysiology of photosynthesis in macroalgae. Photosynth. Res. 113, 105-125.

Ruangchuay, R., Dahamat, S., Chirapat, A., Notoya, M., 2012. Effects of culture conditions on the growth and reproduction of Gut Weed, Ulva intestinalis Linnaeus (Ulvales, Chlorophyta). Songklanakarin J. Sci. Technol. 34, 501-507.

Steller, D.L., Hernandez-Ayon, J.M., Riosmena-Rodriguez, R., Cabello-Pasini, A., 2007. Effect of temperature on photosynthesis, growth and calcification rates of the freeliving coralline alga Lithophyllum margaritae. Cienc. Mar. 33, 441-456.

Tagliarolo, M., Clavier, J., Chauvaud, L., Grall, J., 2013. Carbon emission associated with respiration and calcification of nine gastropod species from the intertidal rocky shore of Western Europe. Mar. Biol. 160, 2891-2901.

Tait, L.W., Schiel, D.R., 2011. Dynamics of productivity in naturally structured macroalgal assemblages: importance of canopy structure on light-use efficiency. Mar. Ecol. Prog. Ser. 421, 97-107.

Thomas, E.A., Tregunna, E.B., 1968. Bicarbonate ion assimilation in photosynthesis by Sargassum muticum. Can. J. Bot. 46, 411-415.

Tomanek, L., Helmuth, B., 2002. Physiological ecology of rocky intertidal organisms: A synergy of concepts. Integr. Comp. Biol. 42, 771-775.

Truchot, J.P., Duhamel-Jouve, A., 1980. Oxygen and carbon-dioxide in the marine intertidal environment - Diurnal and tidal changes in rockpools. Respir. Physiol. 39, 241254.

Underwood, A.J., Jernakoff, P., 1984. The effects of tidal height, wave-exposure, seasonality and rock-pools on grazing and the distribution of intertidal macroalgae in NewSouth-Wales. J. Exp. Mar. Biol. Ecol. 75, 71-96.

Widdows, J., Brinsley, M., 2002. Impact of biotic and abiotic processes on sediment dynamics and the consequences to the structure and functioning of the intertida zone. J. Sea Res. 48, 143-156.

Zander, C.D., Nieder, J., Martin, K., 1999. Vertical Distribution Patterns, Intertidal Fishes. Academic Press, San Diego, pp. 26-53.

Zou, D., Gao, K., Xia, J., Xu, Z., Zhang, X., Liu, S., 2007. Responses of dark respiration in the light to desiccation and temperature in the intertidal macroalga, Ulva lactuca (Chlorophyta) during emersion. Phycologia 46, 363-370. 